\title{
Circulating Tumor Cells Positive
}

National Cancer Institute

\section{Source}

National Cancer Institute. Circulating Tumor Cells Positive. NCI Thesaurus. Code C146691.

An indication that tumor cells have been detected in a peripheral blood sample. 